\title{
Physiographic Control of the Chattanooga Campaign
}

\section{Frederick V. Emerson}

To cite this article: Frederick V. Emerson (1905) Physiographic Control of the Chattanooga Campaign, Journal of Geography, 4:2, 58-73, DOI: 10.1080/00221340508985573

To link to this article: http://dx.doi.org/10.1080/00221340508985573

Published online: 12 May 2008.

Submit your article to this journal \lceil

Џll Article views: 4

Q View related articles $\longleftarrow$ 


\title{
PHYSIOGRAPHIC CONTROL OF THE CHAT- TANOOGA CAMPAIGN*
}

\author{
BY FREDERICK V. EMERSON
}

1 $T$ the opening of the civil war, the leaders of both sides clearly recognized three regions around which important campaigns must center. The confederacy was at a disadvantage in having no marked natural boundaries. The rivers and mountain led into rather than around it. The territory of the seceding states was roughly divided into three physiographic sections, each of which required a separate force. East of the Appalachians were the Piedmont and Coastal Plain regions, the struggle for which centered in the vicinity of Richmond. On the west was the Mississippi Valley, the "gateway to the confederacy."

The middle section included the rugged portions of Kentucky and Tennessee. By a singular combination of surface features the key to all this area lay in the comparatively small region in the vicinity of Chattanooga. It is the purpose of this paper to trace the relations between the campaigns centering about Chattanooga to the topography of the region-their "earth control," as the geographers would say.

"Chattanooga," says Fiske, "was the northern gateway to the center of the confederacy. From it radiated railroads to the Ohio, Mississippi, Gulf and Atlantic; through it were the railroad connections of Virginia with the southwest. Its possession by the federal army would isolate Virginia and North Carolina from the western states of the confederacy, and open a way through Georgia to Atlanta and thence to the coast." On the other hand, its control by the confederates gave them the fertile valleys of east Tennessee and allowed them to threaten Kentucky and western Tennessee. They could readily move troops and supplies between the army in Virginia and the forces in the west. The mountaineers in Kentucky and Tennessee were largely unionists and this provided an additional strong incentive for the federals to control the region.

The importance of Chattanooga during the war and the cause of its industrial development since are largely due to physiographic and geological influences. Within a space of a few miles three different geological structures, each having a characteristic physiographic development, approach each other.

Taking these regions in order, the first to the eastward is the Appalachian. It is an apparent jumble of peaks, ranges and valleys, as a glance

* Reprinted by permission from the Popular Science Monthly, June, 1904. 
at the relief map will show. Their ancient crystalline rocks have weathered with comparative slowness, and consequently the mass stands out in strong relief, extending nearly to the Atlantic and most effectively separating the southern Atlantic seaboard from the interior. So effective a barrier were they that communication from the coastal plain with northern Georgia, Tennessee and Kentucky was either by the passes in Virginia or around the southern end of the mountains by way of Atlanta. Prior to 1880 there was no railroad across these mountains south of Roanoke. Some of the

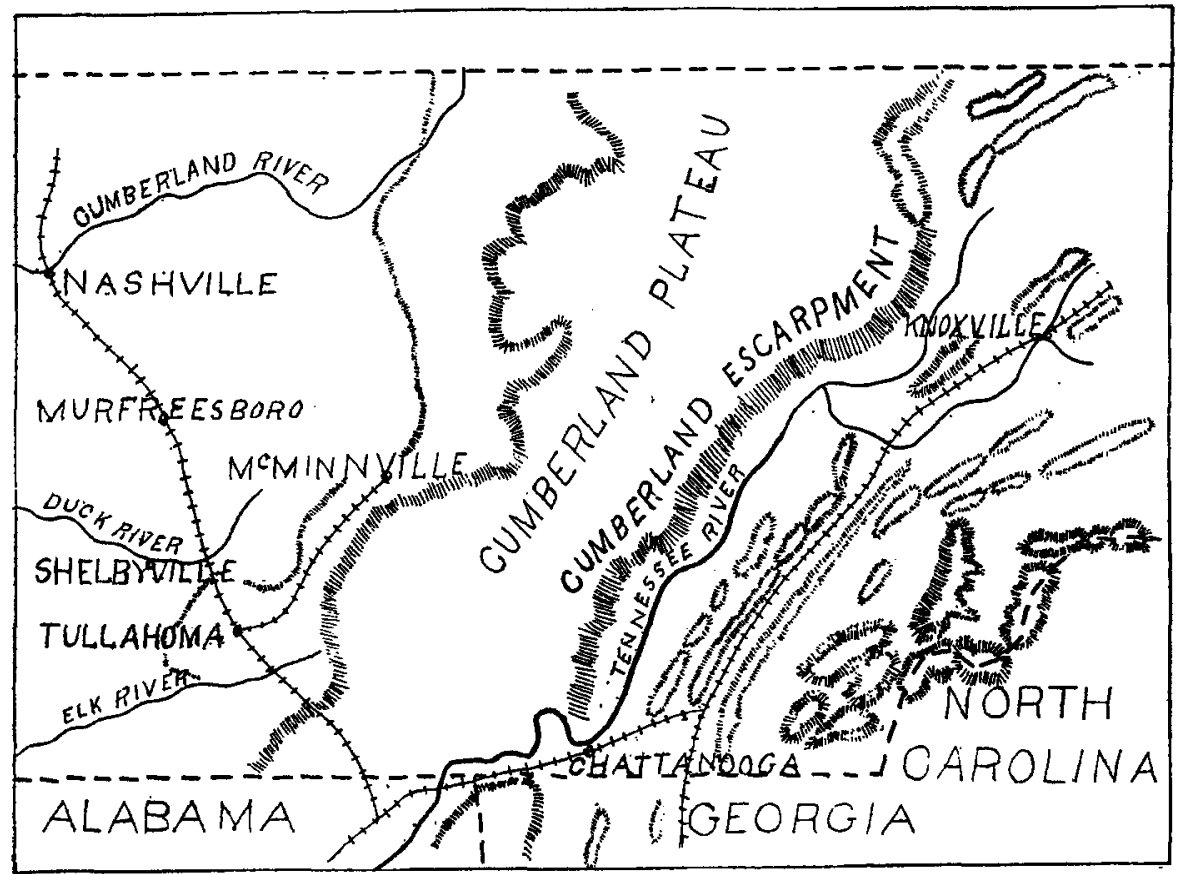

Outline Map of the Region included in the Chattanooga Campaign

intermontane valleys are fertile and support a considerable population, but the general inaccessibility of the region is shown by the life and customs of the people, which have scarcely changed since Revolutionary times.

In the tilting and folding incident to the formation of the Appalachian system, there was exposed a belt of limestones and shales extending in a direction roughly parallel to the mountain axis. These rocks are til.ted and their upturned edges are easily eroded as compared with those on either side. The result of this erosion is an irregular trough from ten to seventy-five miles wide and over a thousand miles long. It is known in general as the 
"Great" or Appalachian valley, but has various local names. In $\mathrm{New}^{\mathrm{r}} \mathrm{Jer}-$ sey it is known as the Kittatinny valley; in Pennsylvania it is the Cumberland valley; in Virginia it becomes the Shenandoah valley and in this region, the Tennessee valley or the East Tennessee valley.

The rocks are much inclined and their parallel edges of different degrees of resistance are exposed to the process of denudation, the results of which are long, narrow, parallel ridges running lengthwise along the valley. For example, the famous Chickamauga Ridge is composed of a compact resistant

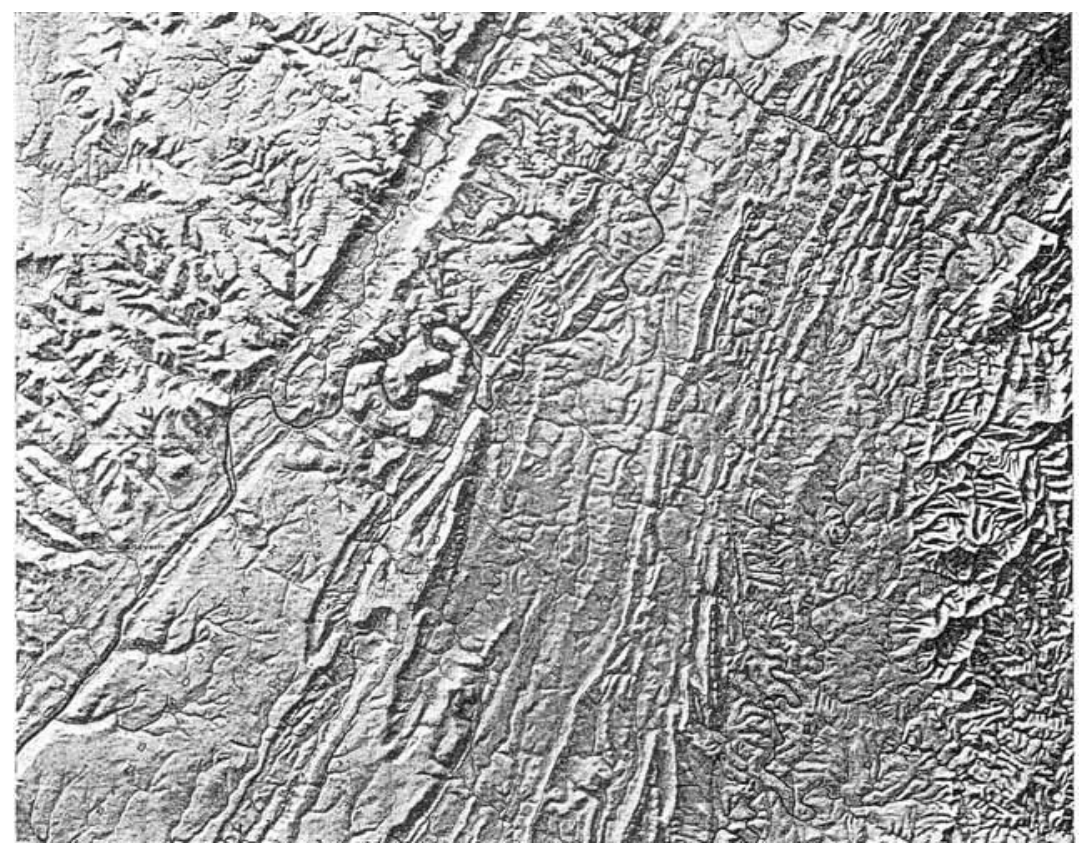

Relief Map of the Chattanooga District. (Photographed from the model by E. E. Howell.)

rock, known as Knox dolomite, which stands above the valley floor because the neighboring strata are less resistant to the levelling effects of denudation. The traveler going through the region is not likely to recognize the valley form, as most of the roads are in smaller valleys between the ridges, but once gain some commanding elevation and the great valley is seen stretching away, its ridges and hills melting into insignificance on its apparently level bottom. The decomposed rock makes a fertile soil which early attracted settlers. From New York to Alabama it is the abode of a prosperous people with well tilled farms and comfortable homes. 
Extending westward from the valley is a plateau region which merges on the north and west into the Mississippi valley and is known as the Cumberland Plateau. The geologist finds no difficulty in accounting for the transition from valley to plateau when the rock arrangement is seen. Here instead of the highly tilted strata of the valley, the rock layers are nearly horizontal. Instead of the troughs and ridges of the valley, the surface, while rough, has an even sky line which tells of a former approximately level

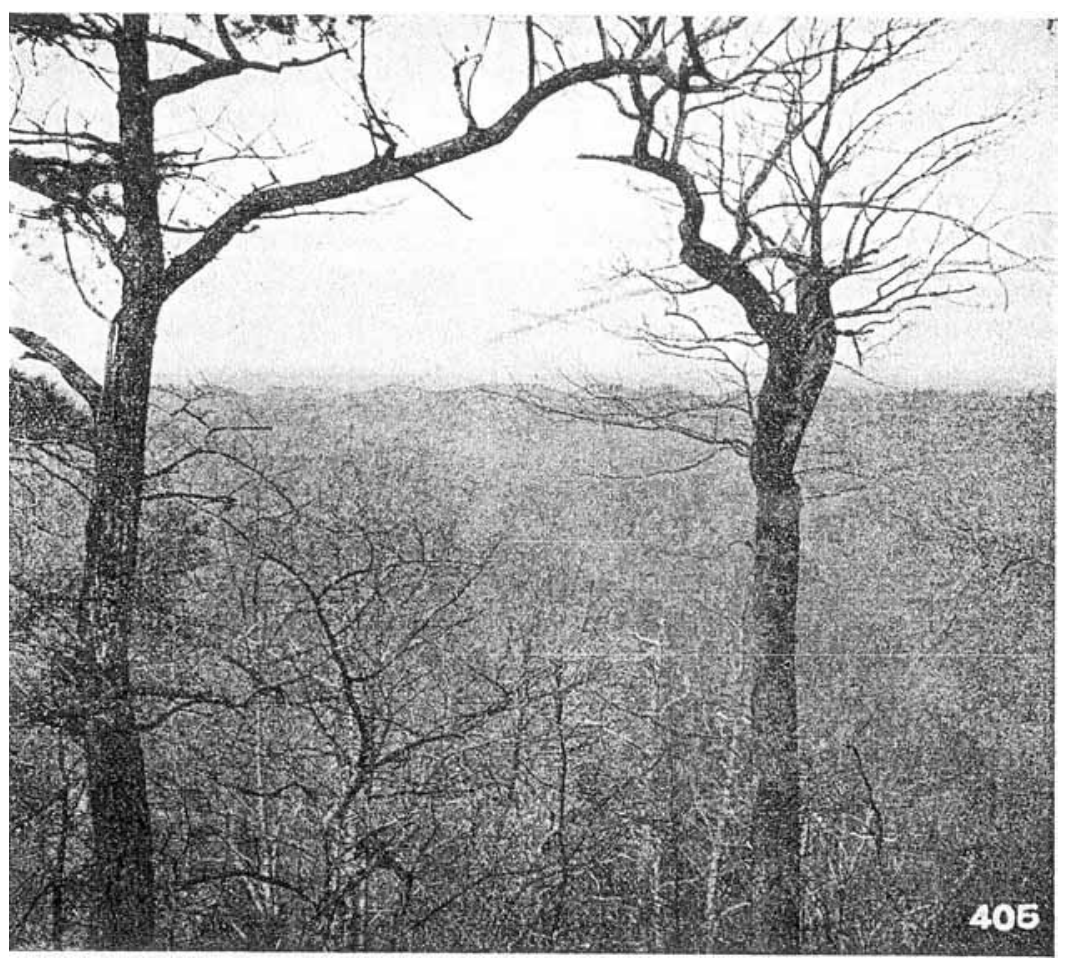

General view showing one of the Appalachian Valley Ridges in Monroe County, Tenn. (Photographed by the U. S. Bureau of Forestry.)

surface. The elevations are steep and the streams seem to have no regular arrangement-in short, this region is a "dissected" plateau. The surface stratum of rock in general is a sandstone which is underlaid by a stratum of more easily soluble limestone. When a stream has cut through the sandstone layer and reaches the limestone, it deepens its valley more rapidly than before and consequently flows in a steep trench.

The overlying sandstone protects the limestone beneath and prevents 
its active weathering, thus the rate of recession of a cliff is entirely regulated by the recession of the overcapping stratum. The general result upon the topography is high, cliff-like valley walls, and rather level-topped hills with steep slopes. Where the plateau meets the Great Valley, this is shown on a grand scale. From Chattanooga northeastward along Walden's ridge for scores of miles stretches a cliff or escarpment which overlooks the valley. It is steep and the streams flowing across the escarpment have gashed it into a serrate profile which gives it the local name of Cumberland Mountain. The lack of roads and general inaccessibility of plateau and escarpment made it a factor to be reckoned with in the movement of armies. The plateau is heavily timbered and, in contrast with the valley, is difficult of access and sparsely settled. The relief map of the Chattanooga district shows the surface appearance of these divisions.

The drainage of these regions is as peculiar and characteristic as are the surface features. The great valley is a structural valley, and not, as are most valleys, the seat of a great river. Its existence, as has before been noted, is due not to river activity, but to the easy denudation of its rocks as compared with those on either side. The only large rivers flowing lengthwise of the valley are the Shenandoah and Tennessee. These and the smaller streams have a general direction parallel to the valley trend. They have discovered strata which they can erode and into which they have sunk their channels. The streams on the plateau have no such succeeding parallel strata to guide their course and have cut valleys in an irregular fashion, not unlike the branching of a tree.

Looking at the course of the Tennessee, it would seem that the river could hardly have taken a more roundabout way to the sea. Rising about seventy miles above Chattanooga, it follows the valley trend until it reaches this place. There, instead of continuing about three hundred miles down the valley to the Gulf, the river turns abruptly to the westward and enters the plateau by a deep gorge. Flowing in a meandering course, it passes through northern Alabama and across Tennessee and Kentucky, entering the Ohio River at Paducah, over fifty miles north of its source. It finally reaches the Gulf after a circuitous journey of more than three times the distance that would be required had it taken the course down the valley. Indeed, some geologists hold that the Tennessee at one time did follow the shorter course, but a tilting of the land together with the rapid erosion eastward of a westward-flowing stream diverted the river to its present course.

The civil war opened with the Chattanooga region in the hands of the confederates who also controlled Tennessee and Kentucky to the north and west. Both sides were fully alive to the importance of the position and for 
over two years it was the objective of the union armies. But at this time Chattanooga was nearly one hundred miles within the confederate lines, which reached from Columbus, a strongly fortified post on the Mississippi, to Cumberland Gap, at the northeast corner of Tennessee, where there was a pass to the Great Valley. At about the center of the line were forts Donelson and Henry, which commanded respectively the Cumberland and Tennesee rivers. These rivers were natural roadways into the confederacy, and it was an important step when Grant captured the forts. The first

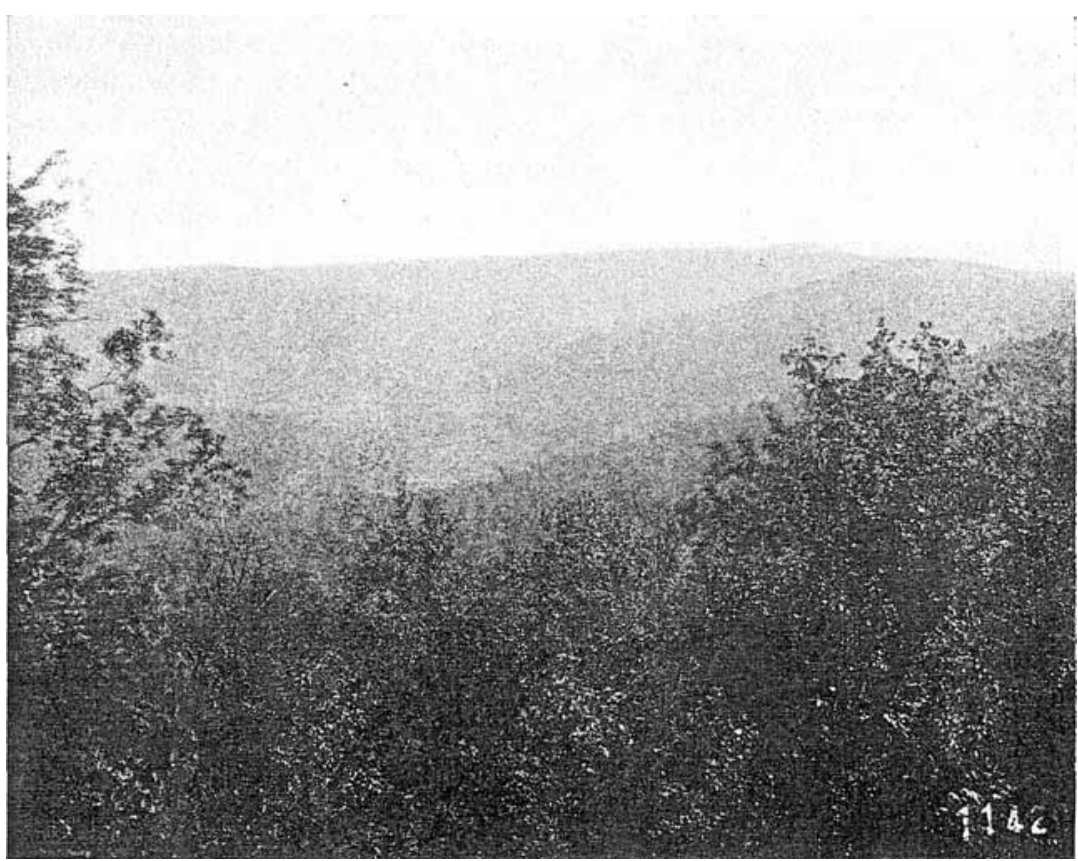

View in the dissected Cumberland Plateau, near Sewanee, Tenn. The Mountains, are formed by denudation, leaving an even sky-line. (Photographed by the U. S. Bureau of Forestry.)

advance toward Chattanooga had been taken, and from now on until its capture Chattanooga was the goal of some Union army in Tennessee.

General Rosecrans was in command of the army which found itself ready to start for Chattanooga, with General Bragg as his opponent. Bragg had attempted an invasion of Kentucky, but was checked at the battle of Stone River, near Murfreesboro, which left the two armies facing each other on the Cumberland plateau. Rosecrans's army and supplies were concentrated at Murfreesboro and Bragg had his center resting at Tullahoma, 
a straggling village important only as a railroad junction. The Tullahoma campaign which now followed was indecisive, but is interesting to the student of military history because of the strategy by which Rosecrans forced his adversary to retreat without incurring serious loss to the federal army. Its consideration is also appropriate in this article, since the plans of the commanders and the movements of their forces were very largely controlled by the physiography of the plateau.

So deeply dissected is this plateau that, without exception, military writers speak of it as the Cumberland "Mountains." Weathering and stream work, continued through untold ages, have cut deep valleys and carved hills until we have the present rough country to cross which, even without an enemy in front, was no small undertaking. The soil, derived from carboniferous sandstone in general is a thin sandy loam, and only in the valley bottoms where the streams have worn a trench and partly filled it with alluvial sediment is the soil fairly fertile.

The plateau with its overlying sandstone is believed once to have extended across middle Tennessee, but active erosion in the vicinity of the larger rivers has removed all but a few remnants of the sandstone and left the underlying limestone to form the floor of the middle Tennessee basin. The Cumberland Plateau is therefore a surviving portion of this old extensive plateau. It is commonly known as the Highland Rim.

The plateau descends towards the plains of middle Tennessee by three great irregular terraces each roughly about five hundred feet high. Through these terraces streams have carved narrow valleys through which the roads pass to the lowlands. These gorges, called "gaps" by the mountaineers, were as important to the armies in that section as were the "wind gaps" between Virginia and the Shenandoah valley to the confederates. They were easy to hold with a small force against a numerous body of the enemy and were especially serviceable to a retreating army, since a small rear guard was able to give complete protection.

The question of railroad transportation was an almost paramount one in these campaigns and, as we have seen, was one of the reasons for the military importance of Chattanooga. The modern army with its concentration of men and horses is rarely able to live on the country through which it passes, especially if it is on an offensive campaign and traversing territory through which the enemy has passed. To do so would involve the spreading of the troops over a large area or detaching a considerable force to forage. Sherman's famous march to the sea was a successful instance of a large army living on the country, but he had no active enemy in his front and was passing through the "garden of the confederacy." If a railroad or river is 
not available for transporting supplies, resort must be had to wagon trains.

The average army wagon was drawn by six mules and carried a day's rations for five hundred men. If the distance were such that the wagon could not make a complete trip in one day, more wagons were required. It was even harder to provide food for the horses. When cattle could be driven it would give some relief to the wagon trains. To give a general idea of the magnitude of this work, it is estimated that it required one thou-

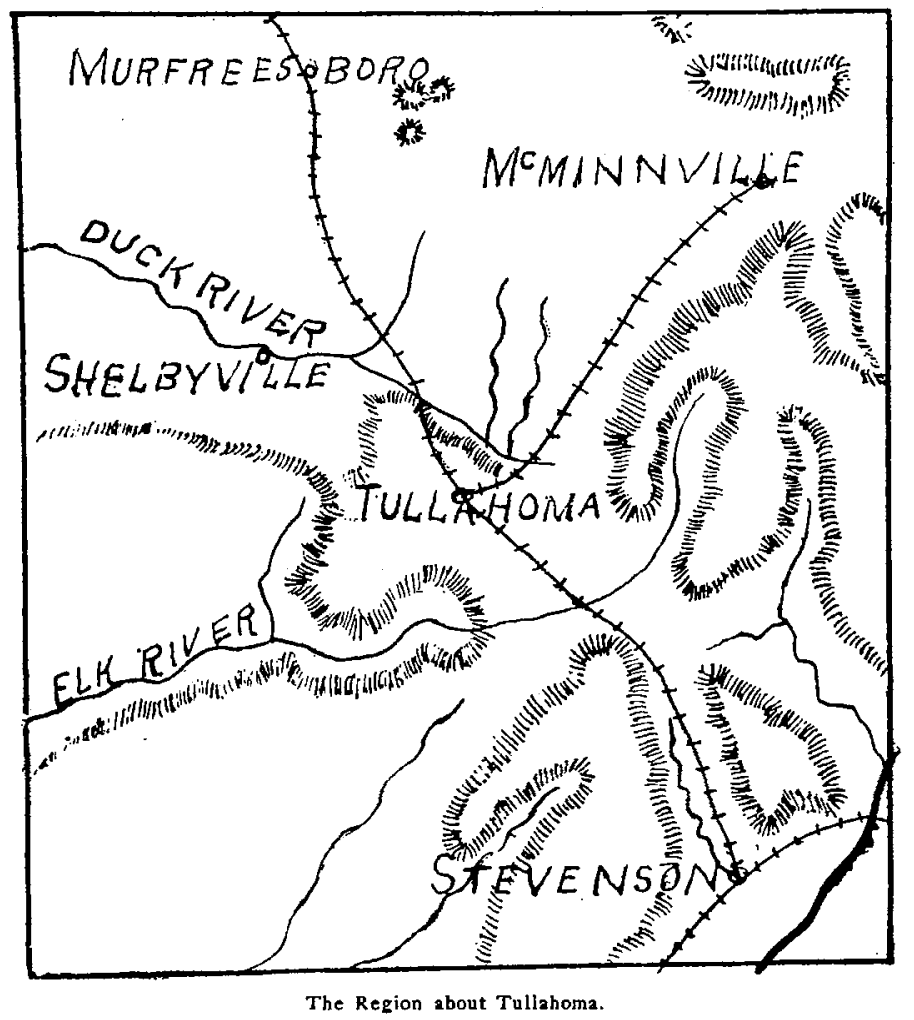

sand wagons and six thousand horses to feed an army of fifty thousand men when they left the railroad or base of supplies for a distance of two days' march. This estimate assumes good roads and no breakdowns or stoppages by the enemy and does not include transporting the sick and wounded or the ammunition and materials of war.

The Louisville and Nashville railroad winds through the plateau following the valleys which the streams have cut. It crosses many streams and deep gorges by wooden bridges which were easy to destroy and difficult to 
rebuild. Both armies were dependent on this road for their supplies. About Tullahoma the soil, before it was cleared, supported a growth of pines and from the general inhospitality of the region was known as the "Pine Barrens." The soil drainage was so easy that in a dry summer there was scarcity of water on the uplands, but in a rain, as one of the federal officers complains, "The soil became as quicksand after a rain, allowing artillery and wagons to sink to the hub." Thus the dependence of the two armies upon the same line of railroad was almost absolute.

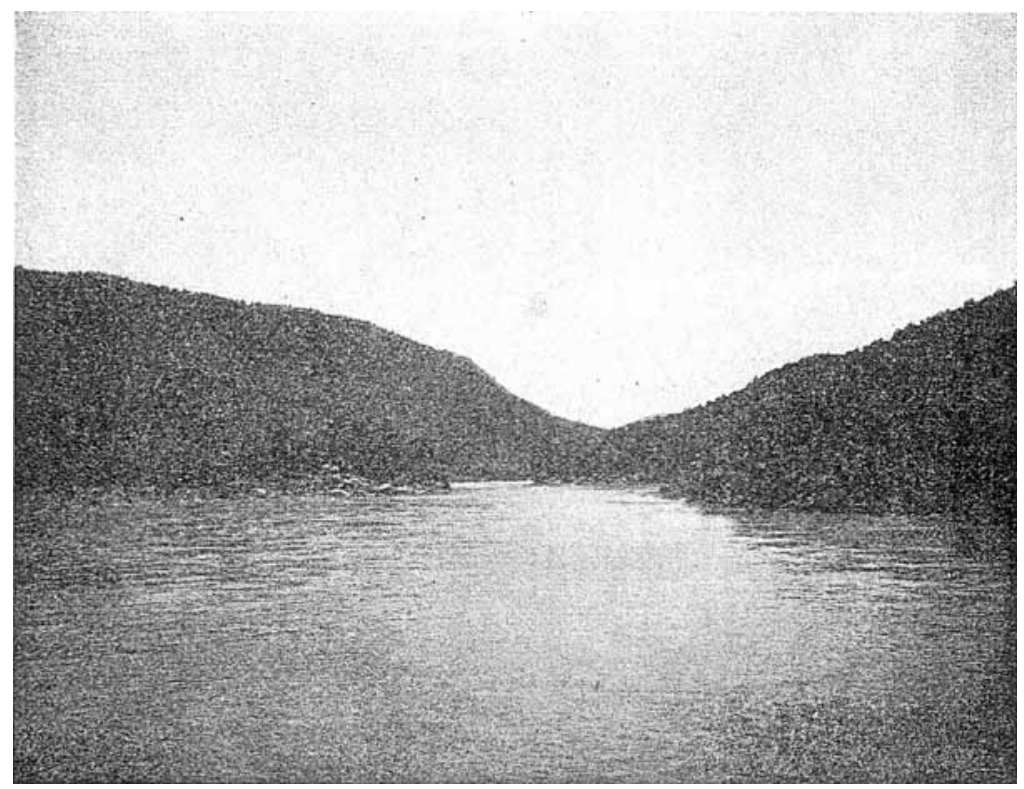

The Tennessee breaking by a Steep Gorge through the "Mountains." Owing to the swift current it is there called the "Suck."

After the battle of Murfreesboro, Bragg's policy was one of defense. His position was strong and well taken. His center and depot of supplies were at Tullahoma, where he had thrown up extensive intrenchments. His left was at Shelbyville on the plateau, about thirty miles to the northwest in the Duck River valley. This town was in a fairly fertile alluvial valley which offered some sustenance for the troops and horses and, further, was a center from which roads diverged in all directions. Morcover, if he were forced from his position, he could retreat to the plateau which could be fairly easily defended. To his right from Tullahoma, Bragg had posted bodies of troops for the double purpose of defense and of threatening the 


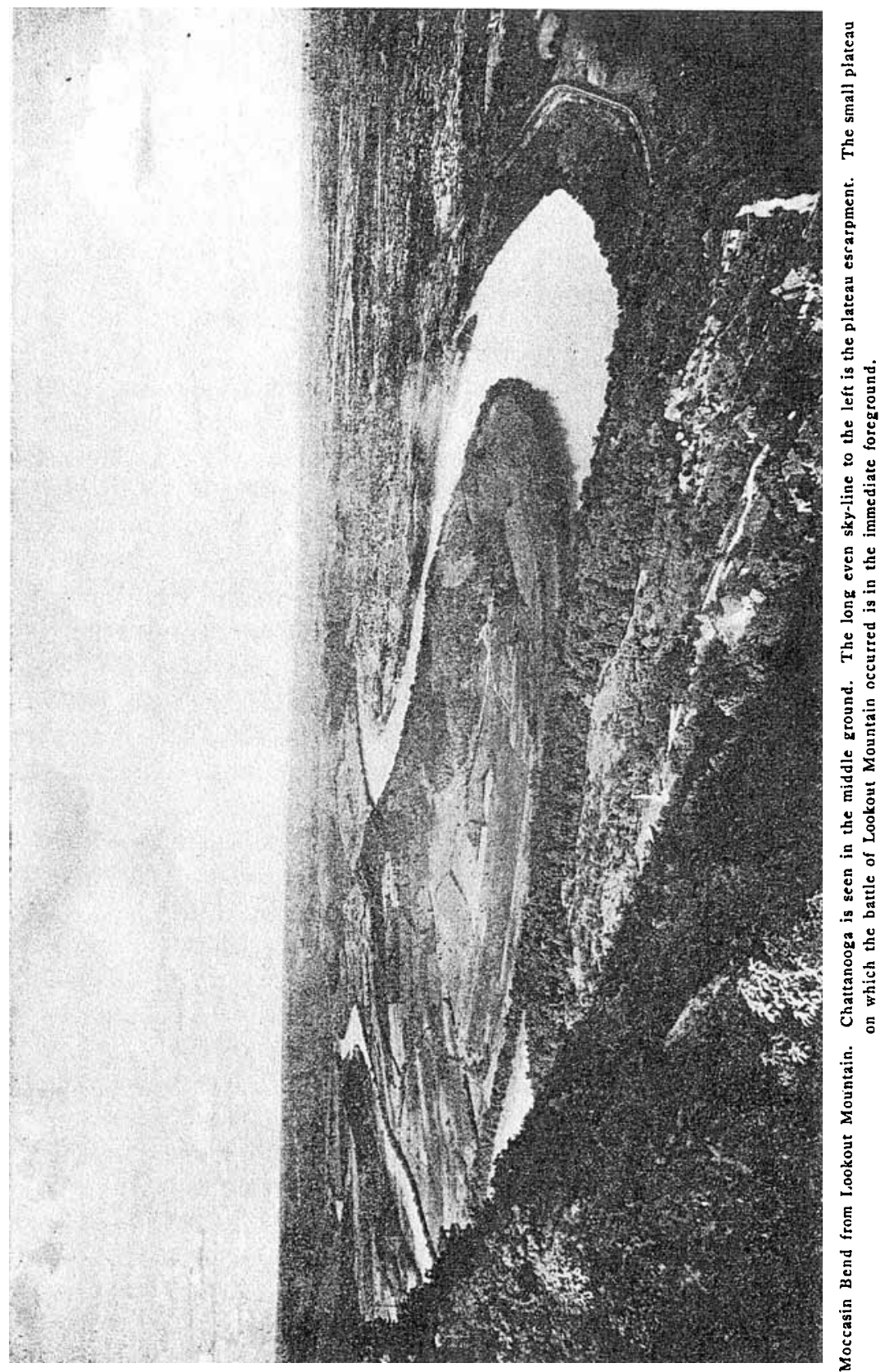


union base at Murfreesboro. His defensive positions were taken where streams passing from one terrace had cut gorges through which roads passed to the plateau, the most important being Hoover's Gap and Liberty Gap. Bragg believed that he had sufficient men in this vicinity to guard the narrow defiles through which most of the roads ran.

Without going into detailed accounts of movements of troops, Rosecrans's plan may be briefly stated. Realizing the strength of Bragg's left at Shelbyville, the Union general resolved to attempt what his opponent evidently considered well-nigh impossible-to get his forces on Bragg's right in such a position as to threaten the latter's line of communication and compel him to evacuate his strong position.

A strong Union force with several days' rations in wagons and on hoof was detached for this movement. A vigorous attack on Bragg's left partly concealed the plan of Rosecrans and prevented him from sending reinforcements from here. The movement was successful and the defiles or "gaps" were secured by which the troops could pass to the level of the plateau on which Tullahoma was situated. The confederate general, not waiting for his line of supplies to be destroyed, retired to the Tennessee, burning the bridges and destroying the railroad as he went. A pursuit was attempted which was entirely ineffectual. Again the narrow stream gorges were an important factor. The passage of the confederate army had left the roads almost impassable and their rear guard had little trouble in defending the defiles through which their columns had passed. Bragg crossed the Tennessee and leisurely led his army into Chattanooga.

At this stage the immediate topography of Chattanooga and its vicinity became important in determining the military movements. Looking at the relief map it will be seen that the city lies at the western side of the Great Valley close to where the river breaks into the plateau. It winds through Sand Mountain in a deep gorge which narrows in places, making the current so swift that an ordinary steamboat could not ascend without aid from teams or men on the shore. When the river reaches a long, narrow trough, called the Sequatchie valley, it takes this easier path and flows sixty miles before again crossing the plateau in its indirect course to the Ohio. Near the city the river flows to Lookout Mountain and then doubles on itself, flowing northwesterly, almost parallel to its course, for several miles. This is the famous Moccasin bend, so called, of course, from its rough resemblance to an Indian's moccasin. At the apex of the bend towers Lookout Mountain, the most conspicuous feature of the vicinity. Geologically it is a part of the plateau from which it is separated by a narrow erosion valley. It is capped by a sandstone stratum which slopes to the 
south, where it finally merges into the general level in Alabama. Its bold profile against the sky at once attracts the eye, and the name is decidedly appropriate, since on a clear day several states can be seen from the summit. The ridge, for so it must be called instead of "mountain," rises in slopes so steep that they were insurmountable by an army, while its summit is fourteen hundred feet above the rapid current. A mile or so eastward is Missionary Ridge, roughly parallel to Lookout, but much lower and more accessible. Its top is really a succession of hills or knobs. Between these ridges is Chattanooga Creek, which enters the Tennessee near Chattanooga.

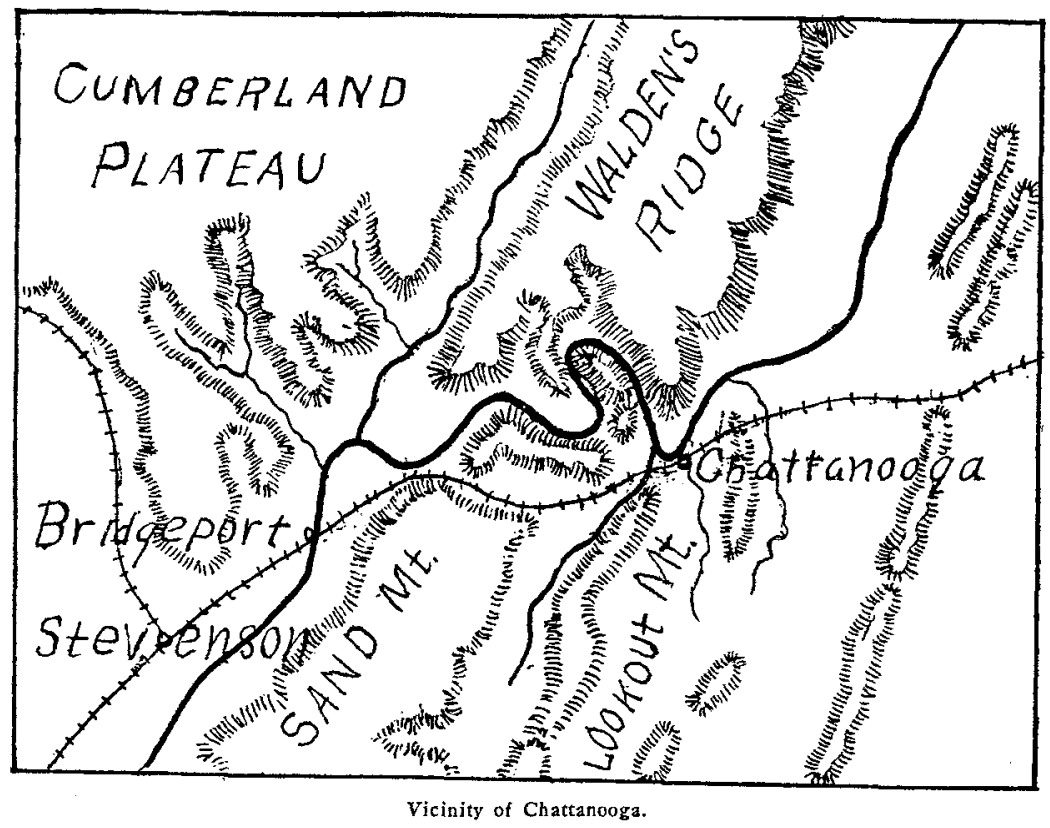

Still to the eastward of Missionary Ridge is the famous Chickamauga Creek. Looking westward from Lookout summit, the view is wild and picturesque in the extreme. Extending to the base of the mountain the valley of Lookout Creek is seen in the immediate foreground. Beyond that is the rough Sand Mountain, whose name tells the story of its rock structure and suggests its scraggly covering of trees and shrubs. To the northwest the river winds in its narrow gorge in the plateau for a few miles and disappears around Sand Mountain. North of the river Sand Mountain is continued and known as Walden's Ridge.

Returning to the military movements, we find Rosecrans on the Cumberland plateau, in the vicinity of McMinnville. For some time he was busy 
repairing the seventy miles of railroad leading from Murfreesboro towards Chattanooga, which the conferedates had destroyed in their movement southward. Some of the bridges of this road were destroyed and rebuilt four times in the course of the war. The Chattanooga and Nashville railroad passed to Stevenson, a small town about thirty miles down the river from Chattanooga, where it joined the railroad leading from Chattanooga to Memphis on the Mississippi. Stevenson was the federal base of supplies. The road then crosses the river at Bridgeport, crosses through a ravine, a

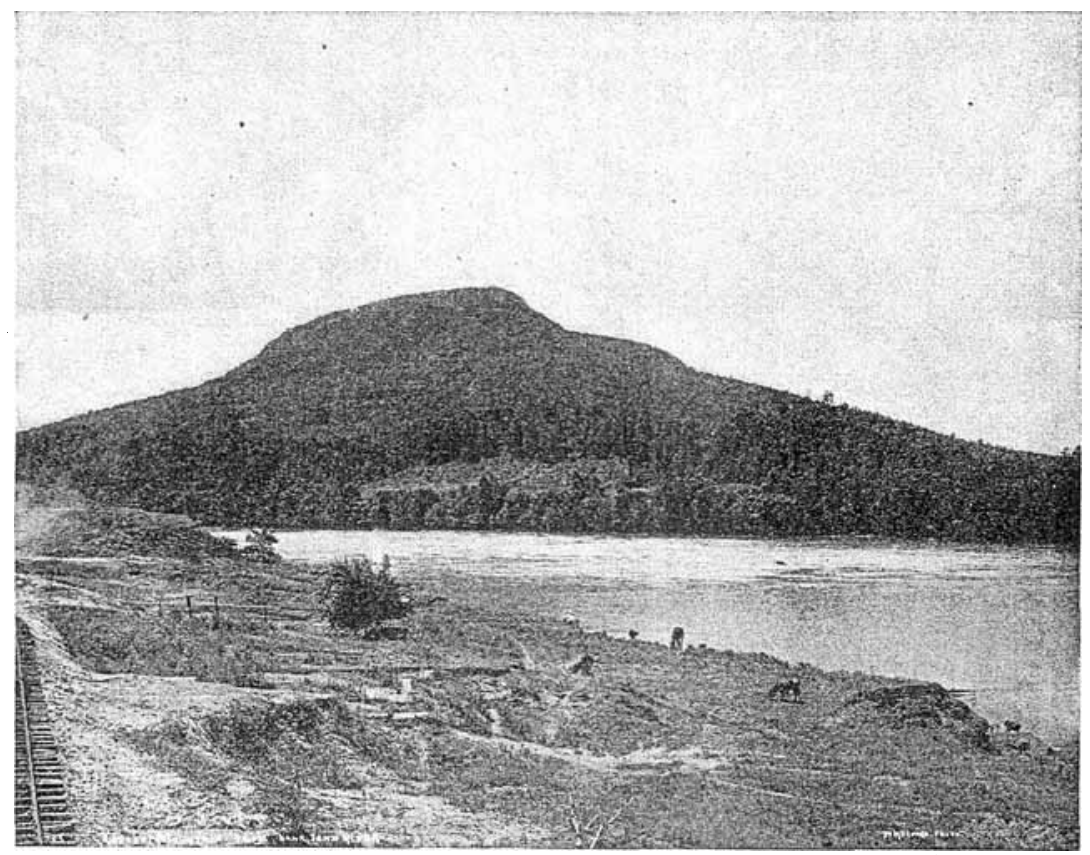

Lookout Mountain from the Bank of the Tennessee River. Hooker's forces ascended the north slope and the battle took place on a small plateau or shelf, seen about half way up the mountain.

spur of Sand Mountain into Lookout Valley, and thence passes around the northern end of Lookout Mountain into Chattanooga. To protect this line Rosecrans was obliged to detail thousands of his troops; each bridge was guarded by a detachment of soldiers who generally had built a stockade in the vicinity. The country was swarming with detached bands of hostile "guerillas" who would wreck a train or burn a bridge and then escape.

The Union commander had open to him two approaches to Chattanooga. He could advance over Walden's Rigge directly upon the city, but this 
route was beset with difficulties. The roads were very poor and led over the hilly, wooded plateau. After a rain they speedily became impassable to wagons. His base of supplies and nearest railroad point was at Stevenson, from which he would be compelled to haul supplies for the army in the presence of an enemy well supplied with cavalry; moreover, he would have to cross the river in boats at Chattanooga in the face of a vigilant foe. In spite of its difficulties this was the way which Rosecrans was generally expected to take, as it was thought that Burnside, who was near Knoxville, up the valley, would come down and join in the movement.

The other approach lay along the river valley and across Sand Mountain. The advantage of this route was that the army was near its base of supplies, with which it had both river and railroad connection. However, the roads were poor and the route lay across parallel ridges, almost inaccessible except in a few places. It would be hard to maintain a compact advance over the rough country, and a regiment of the enemy could easily delay an army. Rosecrans chose this route and the manner in which he maneuvered his army was certainly a brilliant piece of strategy.

Bragg had expected the federal army to come over Walden's Ridge, and Rosecrans did all in his power to strengthen that belief. Troops were deployed in front of Chattanooga and at night camp fires were lighted on the hills above the river. By feinting in this way Rosecrans was able to advance his army into Lookout Valley without encountering opposition. From here he went through the passes of Lookout Mountain into Chattanooga Valley and threatened Bragg's line of communication with the south. Bragg led his army out and, after a series of maneuvers, the battle of Chickamauga was fought with disastrous results to the federals. Had it not been for the stand made by Thomas, the "Rock of Chickamauga," the Union army would have been routed. As it was, they were driven into Chattanooga and imprisoned by a seemingly impregnable line of works. Lookout Mountain was abandoned and at once occupied by the confederates. It was apparently the key to the situation.

Rosecrans had caught the wolf by the ears. He had gained Chattanooga, but was a prisoner in its outworks. To advance against the strongly entrenched enemy was folly. To retreat across the plateau would have demoralized his army besides losing the position he had won at such cost. Worst of all, the enemy had taken possession of Lookout Mountain, which Rosecrans had felt obliged to abandon. They had fortified the position and placed guns which commanded the river and railroad west of Chattanooga, thus cutting off supplies from that direction. For awhile provisions came over the Cumberland plateau, but the hardships of the route soon exhausted 
the teams which could not follow the river, as that was patrolled by the enemy's pickets, and were obliged to take circuitous roads over the hills and away from the river. The cattle that were driven that way were hardly able to stand alone, much less furnish sustenance. The soldiers with grim humor spoke of them as "dried beef on the hoof." Bragg, confident of his game, sat down and waited for the Union army to be starved into surrendering, and his hopes did not seem unreasonable.

The north was thoroughly alarmed at this state of affairs and Grant was put in command. His first work was to open a line by which supplies could reach the city. The celerity with which he accomplished this makes one wonder why it was not done before. The only feasible route was up the river, but the works on Lookout Mountain controlled both the river and the railroad west of the town. Down the river and out of range of the guns on Lookout was Brown's ferry, which was guarded by a force of confederates. Hooker's division, which had been brought from the east, was thrown across the river and, capturing the force there, entrenched a position commanding the river, which was now clear below this point.

The famine in Chattanooga soon ended. Supplies came to Bridgeport, from thence to Brown's ferry, which Hooker was guarding, and then by wagon to the army. The soldiers were soon well fed and clothed by the "cracker route," as it was appropriately called.

Grant was now free to develop offensive plans. It will be remembered that Bragg's lines stretched from his left on Lookout Mountain to Missionary Ridge, where his right was strongly entrenched; Thomas was to threaten the confederate center, Sherman was to attack heavily on Missionary Ridge and Hooker was to move on Lookout Mountain and the enemy's left.

The latter's movement in the celebrated "battle above the clouds" was successful. However, since the establishment of the new line of supplies, Lookout had ceased to be the key to the position. Sherman found the opposing works stronger than he expected and he was not immediately successful. However, in the center the unexpected happened. This position was believed to be too strong to be carried by direct assault and the attack was intended to prevent reinforcements being sent against Sherman. The troops had orders to stop at the first rifle pits, but they could not be restrained. They rushed up the steep slope, carried the position and the confederate center was broken. Bragg was badly beaten and withdrew to Dalton. The region was not out of Union hands during the rest of the war.

Chattanooga's importance has not ceased with the close of the war. Its position at the gateway between the grain and cotton states, together with the resources of the surrounding country, makes the location of an important 
city in this region almost inevitable. Since the war, the river has been made navigable most of the year to the Ohio. Railroads have multiplied and eleven lines enter the city. Iron, coal, limestone, cotton, lumber, grain are near at hand in the valley and plateau. The city's population and manufactories have doubled in a few years. The battlefields in the vicinity have been surveyed and mapped and the Chattanooga and Chickamauga parks rank with Gettysburg among the military parks of the world.

At a point near Chattanooga one can view the two aspects of the place without changing his position. In the beautiful national cemetery rest over twelve thousand veterans of ' 63 . Turning a little, the city is in view. Its factories are a prophecy not only of the city, but as well of the New South.

\section{COMMERCIAL JAPAN IN 1904}

Japan and its relation to the territory bordering on the Pacific Ocean is the title of the map. Comparison of this with a good physical map of the Empire brings out the geographic reasons for the distribution of tea and rice-growing. The next treatment is semi-historical, beginning with a brief statement of the earlier commercial relations and then taking up the present conditions. Japan's reliance upon the United States for certain commodities, notably cotton, illuminating oil and iron and steel, is shown to be mainly due to geographic conditions, while her exports to America, especially silk, tea, matting, bamboo and lacquered ware, are commodities which we are unable to produce. A trade thus based on geographic differences must be fairly enduring and mutually beneficial.

Foreigners in Japan, to the number of 11,684 , are mostly classed as merchants and men of other professions. Of the Japanese in other lands 72 per cent., or 90,146 , reside in the United States, and about 30,000 more are in Oriental lands, Korea, China, Russian and English colonies. Thus a very small per cent. of the Japanese with foreign residence are in Western countries other than the United States. Both the export and import business of Japan are conducted largely by resident foreigners. A good article, treating of the effects of Japan's commercial development on her civilization, and prepared by a Japanese student in America, will be read with interest. The monograph discusses the more important trades and industries as to their present condition and prospects. Elaborate statistical tables of actual conditions and comparative growth in production and commerce constitute at least one-third of the publication.-Bull. Am. Geog Soc., January, 1905. 